\title{
Revolution's aftershocks still rattling Egyptian universities
}

Fight for campus access symptomatic of larger problems facing scientific research.

\section{Katharine Sanderson}

22 November 2012

A pitched battle between two scientific institutions highlights the difficulties facing Egyptian research, which is being held back by a government in chaos in the wake of the country's revolution, observers say. This week an Egyptian court overturned prime ministerial decrees at the heart of a fight for access to Nile University (NU), a private, not-for-profit research institute near Cairo.

The dispute began in early 2011, when, in the wake of the Egyptian revolution, buildings that had been allocated to NU by ousted president Hosni Mubarak's government were returned to the country's flagship science project: the Zewail City of Science and Technology, led by Ahmed Zewail, an Egyptian chemist and Nobel laureate who is based at the California Institute of Technology in Pasadena.

The current government now needs to act on the court's decision before the NU students are allowed back on to the campus, but both sides have different interpretations of exactly how much of the campus the verdict relates to.

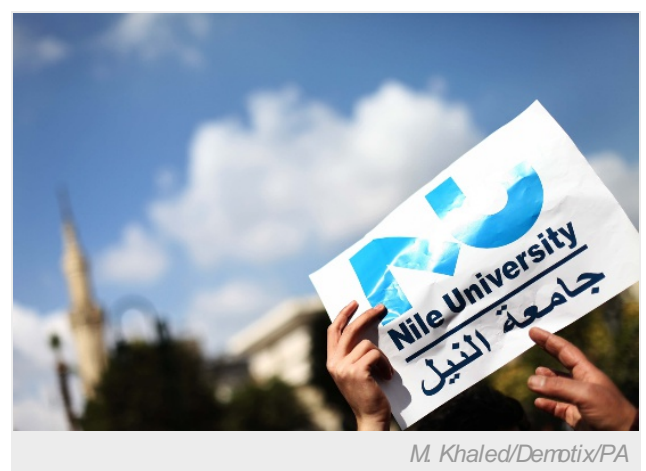

Nile University and the Zewail City of Science and Technology have been locked in a protracted legal battle over the ownership of their campus.

\section{Science, interrupted}

This and other disruptions caused by post-revolution regime changes are adding to concerns about the future of scientific research in Egypt. "There is some sort of administrative chaos" that might hinder progress, says Nazar Hassan, unit chief in science and technology at the United Nations Educational, Scientific and Cultural Organization (UNESCO) in Cairo.

Mohamed Abdel-Mottaleb, NU's nanotechnology programme director, says that things have become worse for researchers since the revolution. "Lots of funding has dried up," he says. And he is concerned that science, technology and research are not a priority in the first draft of the new constitution. "This sends the wrong message," he says.

Hassan says that universities need to be given more autonomy to make decisions. At present, the Egyptian government sets student numbers and must approve all degree programmes offered by a university. "There are a lot of restrictions on universities," says Hassan.

Progress in improving Egypt's research envirnoment is slower than Hassan had hoped. "The talk is there, but who is going to set up a strategy?" he asks. "Administrators are waiting to see what will happen [with the government] before they make any decisions."

But things are moving forward. On 19 November Hassan met with the directors of Egypt's Science and Technology Development Fund and Education Development Fund, along with 30 vice-principals of public universities. "We were talking about what we can actually do to make things better," says Hassan. This includes offering graduates diplomas that do not need to be accredited by the government, which would give the universities more autonomy in what they teach, and making efforts to bring together industry and academia to promote entrepreneurship and innovation. These initiatives are part of UNESCO's Network for Expansion of Converging Technologies in the Arab Region project, launched in 2011.

\section{Uncertain outcomes}

There had been hope that Zewail's project would revitalize science and technology in the region. But the NU conflict might change things. "I don't know if Zewail will take it lying down," says Morad Abou-Sabe, a cell biologist at Kean University in Union, New Jersey, and former president of the private Misr University for Science and Technology near Cairo. There are concerns that Zewail might now leave the project. Moustafa Ghanem, vice-president for research at NU says that this would be a shame. "We are not against Zewail City as a project," he says. 
But Tyseer Aboulnasr, an electrical engineer who is spending time at NU while on leave from her position at the University of British Columbia in Vancouver, Canada, thinks that there is still a chance for the two institutions to work together to drive research and innovation in Egypt. "I believe the conflict was ludicrous to start with and did not have to happen," she says. She hopes that both institutions can work together in future despite being adversaries now, and adds that fostering healthy competition between them will help to propel research in Egypt forward.

Abou Sabe agrees: "These two elements could be a very positive force," he says.

Nature | doi:10.1038/nature.2012.11870 